\title{
Optimization of Crystal Violet Dye Removal in Fixed Bed Column Using Eucalyptus camaldulensis as a Low-Cost Adsorbent
}

\author{
Mansoor Akhtar 1,*(i), Shifa Ullah Khan ${ }^{1}$, Noreen Mazhar ${ }^{2}$, Muhammad Naveed ${ }^{3}$, Qazi Muhammad \\ Yasir $^{3}$, Waqas Ahmed ${ }^{4}$ \\ Faculty of Chemistry, Northeast Normal University, Changchun, 130024, Jilin, China \\ Institute of Chemistry, University of Punjab, Quaid-e-Azam Campus, Lahore-54590, Pakistan \\ School of Geographical Sciences, Northeast Normal University, Changchun, 130024, China \\ 4 College of Veterinary and Animal Sciences (CVAS), Narowal (Sub-campus), University of Veterinary and Animal \\ Sciences, Lahore \\ * Correspondence: akt100@nenu.edu.cn (M.A.);
}

Scopus Author ID 57191956119

Received: 24.07.2021; Revised: 3.09.2021; Accepted: 7.09.2021; Published: 31.10.2021

\begin{abstract}
Adsorption through waste adsorbents is one of the developing technologies used for treating textile wastewater. The present study explores the possible outcome of Eucalyptus camaldulensis biomass as an adsorbent for removing crystal violet dye from aqueous solutions. Eucalyptus camaldulensis biomass was used as such and used in fixed bed column mode to testify its potential at different parameters. Effect of different constraints like bed height $(\mathrm{cm})$, flow rate $\left(\mathrm{mlmin}^{-1}\right)$, initial dye concentration $\left(\mathrm{mgL}^{-1}\right)$, and $\mathrm{pH}$ were studied along with breakthrough curve and exhaust time. Maximum breakthrough curve and exhaust time and utilization of mass transfer zone were observed at bed height of $20 \mathrm{~cm}$. However, the promising results are obtained at higher dye concentration $\left(50 \mathrm{mgL}^{-1}\right)$, lower flow rate $\left(1 \mathrm{mlmin}^{-1}\right)$, and at lower $\mathrm{pH}$ of 5 . This study reveals promising results at acidic $\mathrm{pH}$. This study reflects that adsorption capacity and breakthrough curve favor lower acidic $\mathrm{pH}$. The adsorption data in batch mode follow the Langmuir isotherm and best fit to pseudo-second-order reaction kinetics. The breakthrough curve and mass transfer zone are individually testified, and the breakthrough curve obeys the assumptions of the Thomas model, and $\mathrm{R}^{2}(0.933-0.997)$ values confirm the data that its best fit with the Thomas model.
\end{abstract}

Keywords: adsorbent material; breakthrough, Thomas model; Eucalyptus camaldulensis.

(C) 2021 by the authors. This article is an open-access article distributed under the terms and conditions of the Creative Commons Attribution (CC BY) license (https://creativecommons.org/licenses/by/4.0/).

\section{Introduction}

The textile industry is one of the most important industries in Asia. Many processes are associated with yarn and fabric manufacturing and are termed wet processing, including dyeing, finishing, and printing. The dyeing and finishing process consumes a lot of freshwater used in multiple washing and rinsing cycles. In a typical dyeing and finishing mill, about 150 $\mathrm{m}^{3}$ of water is consumed on average for every ton of cloths processed [1-5]. A huge amount of textile wastewater is released directly into the streams containing contaminants like color. A large number of suspended solids, fluctuating $\mathrm{pH}$, high temperature, and high chemical oxygen demand concentration were generated [6,7]. Basic dyes pre-owned for reform polyesters, cation dyeable polyethylene terephthalate, paper, polyacrylonitrile, reform nylons, and use in medicines. Initially, they were pre-owned for tannin-mordant cotton, wool, and silk. These 
dyes are water-soluble and produce colored cations in the solution and, because of this factor, are termed cationic dyes. The leading chemical classes are oxazine, acridine, thiazine, triarylmethane, diazahemicyanine, cyanine, and hemi cyanine. Dyes are one of the most hazardous chemical compound classes found in industrial effluents, which need to be treated since their presence in water bodies reduces light penetration, precluding the photosynthesis of aqueous flora [8-15]. They are also aesthetically objectionable for drinking and other purposes. Dyes can also cause allergy, dermatitis, skin irritation and provoke cancer in humans [16-24].

Crystal violet is also termed basic violet 3 , gentian violet, and methyl violet 10B. Its molecular weight is 407.98, and it belongs to a class of triarylmethane dyes [25]. The maximum wavelength of crystal violet dye is $594 \mathrm{~nm}$. This dye is widely used in textile fabrics such as cotton and silk, paints, and printing ink. This dye has the ability to irritate the eye [26-30]. This dye also has the ability to cause to cause severe injury in the cornea and conjunctiva as the product has cationic dye features, and it also causes toxicity to mammalian cells. It also affects the skin, causes irritation to it, and affects the digestive system too. If this dye goes in extreme cases, then it may cause kidney failure and permanent blindness. All the above consequences of this dye motivated me to research to remove its effects from the wastewater [31-35].

Adsorption is one of the attractive methods for treating dye wastewater due to its low cost and availability of the adsorbents [36]. Adsorption is the process of accumulating substances that are in solution on a suitable solid surface. It involves the mass transfer operation in which contaminant in the liquid phase is transferred to the solid phase. Different adsorption techniques rely on the attraction between the solid surface and the adsorbate molecules that is physical. The adsorption is referred to as physical adsorption (physisorption) due to weaker Van der Waals forces [37]. When the attraction forces are due to chemical bonding, the Adsorption process is termed chemisorption. In view of the higher strength of the bonding in chemisorption, it is difficult to remove the chemisorbed contaminant from the solid surface. Major adsorbents include activated carbon, synthetic polymeric, and silica-based adsorbent $[38,39]$.

Change in the $\mathrm{pH}$ values also influences the breakthrough curves values. The behavior of dyes adsorption can be optimized at different $\mathrm{pH}$ values, i.e., 3.0 to 11.0. The slow saturation rate and breakthrough curve shift are observed at basic $\mathrm{pH}$ during the adsorption of methylene blue. This indicates that the binding sites of the adsorbent; contain the opposite charges which attract each other between the adsorbate and adsorbent. The adsorbent is negatively charged, and the adsorbate has a positive charge cause the force of attraction and adsorption to occur [40-48]. Different curves can be obtained by varying the flow rate and bed height. Breakthrough curves values are taken at equal intervals of time, while saturation values are measured with the help of a double beam spectrophotometer.

The present study aims to optimize the crystal violet dye removal from an aqueous solution using Eucalyptus camaldulensis as a low-cost adsorbent in a fixed bed column. To validate the Thomas model application, the batch experiment has been carried out at different initial dye concentrations [49,50].

\section{Materials and Methods}

\subsection{Adsorbent preparation.}

Eucalyptus camaldulensis bark was collected from the premises of COMSATS Institute of Information Technology, Abbottabad. The bark was collected from the eucalyptus tree 
during the autumn season. The bark was washed from the deionized water to remove the dust particles and other contaminants. After washing, the bark was sun-dried for a few days and then crushed by JM disk mill. After sieving, a particle size of $40 \mathrm{mesh}$ size $(420 \mu \mathrm{m})$ was used throughout the experimental studies. The biomass was stored in air-tight packed bags [25].

\subsection{Activated carbon prepared by physical activation.}

The process requires hot gases to activate the adsorbent. This process goes under two steps, i.e., Carbonization and activation. Carbonization is carried out by pyrolysis at high temperatures $\left(300^{\circ} \mathrm{C}\right)$ in the presence of nitrogen gas. Then heating is carried out for many hours for physical activation of Eucalyptus bark [14].

\subsection{Chemicals and reagents preparation.}

\subsubsection{Preparation of crystal violet dye stock solution.}

A stock solution of crystal violet dye with $250 \mathrm{mgL}^{-1}$ concentration was prepared by dissolving $0.25 \mathrm{gm}$ analytical grade (Merck) crystal violet dye in $250 \mathrm{~mL}$ of deionized water. Suitable dilutions were made for obtaining different dye concentrations using the following formula:

$$
\mathrm{C}_{1} \mathrm{~V}_{1}=\mathrm{C}_{2} \mathrm{~V}_{2}
$$

Where, $\mathrm{C} 1$ concentration of the stock solution, $\mathrm{V} 1$ volume of stock solution need, $\mathrm{C} 2$ required concentration, V2 volume of the required diluted aqueous solution

\subsubsection{Preparation of $0.1 \mathrm{M} \mathrm{HNO}_{3}$ and $0.1 \mathrm{M} \mathrm{NaOH}$ solution.}

In this experiment, the adsorbent is tested for dye removal efficiency on different $\mathrm{pH}$. The experiments were conducted under different acidic (5 and 6) and basic $\mathrm{pH}$ (9 and 11), which were adjusted through acid and base solution, i.e., $\mathrm{HNO}_{3}$ and $\mathrm{NaOH}$, respectively. 0.1 Molar $\mathrm{HNO}_{3}$ was prepared by adding $0.8 \mathrm{~mL}$ of $\mathrm{HNO} 3$ into $100 \mathrm{~mL}$ of deionized water. Likewise, 0.1 Molar $\mathrm{NaOH}$ solution was prepared by adding $400 \mathrm{mg}$ of analytical grade $\mathrm{NaOH}$ in $100 \mathrm{mLof}$ deionized water.

\subsection{Batch adsorption experiments.}

Kinetics batch experiments were conducted by taking $0.05 \mathrm{~g}$ of Eucalyptus camaldulensis bark into $50 \mathrm{~mL}$ of deionized water in Erlenmeyer flasks. The initial $\mathrm{pH}$, i.e., 6.5, was maintained using buffer solution, and $\mathrm{pH}$ was determined using a PHS-3BW microprocessor $\mathrm{pH} /$ temperature meter. After preparation, the solution was shaken in the orbital shaking incubator (wise cube WIS-20) at $220 \mathrm{rpm}$ for $120 \mathrm{~min}$ at room temperature $30^{\circ} \mathrm{C} \pm 1^{\circ} \mathrm{C}$ [30]. The adsorbed dye was then measured through T80+UV/VIS Spectrometer at a wavelength of $590 \mathrm{~nm}$. The amount of crystal violet dye adsorbed by the adsorbent was calculated from the following equation:

$$
Q=\left(C_{0}-C_{f}\right)_{M}
$$

Where, Q dye uptake $\left(\mathrm{mgg}^{-1}\right)$, Co initial dye concentration $\left(\mathrm{mgL}^{-1}\right)$, Cf Final dye concentration $\left(\mathrm{mgL}^{-1}\right), \mathrm{M}$ adsorbent mass $(\mathrm{g})$. 
2.5. Effect of initial dye concentration.

Batch experiments were carried out using different initial crystal violet dye concentrations, i.e., 20, 30, $60 \mathrm{mgL}^{-1}$. The adsorbent and dye mixture was shaken using $1 \mathrm{gL}^{-1}$ for $2 \mathrm{~h} \mathrm{[10].}$

\subsection{Column studies.}

2.6.1. Fixed bed bio adsorption studies.

A continuous flow bio adsorption experiment was conducted in a glass tube having an internal diameter of $2 \mathrm{~cm}$ and $50 \mathrm{~cm}$ in length. Eucalyptus bark was packed into a glass column to obtain the desired bed height. The bed top was covered with a layer of glass wool to avoid the loss of bioadsorbent and to ensure a close-packed arrangement. Afterward, dye solution of the known concentration at desired $\mathrm{pH}$ was pumped downward with the help of a peristaltic pump with desired flow rate at room temperature. A series of experiments were conducted to study the effect of flow rate and bed height. The samples were analyzed through a UV spectrophotometer at regular intervals of time [23,25].

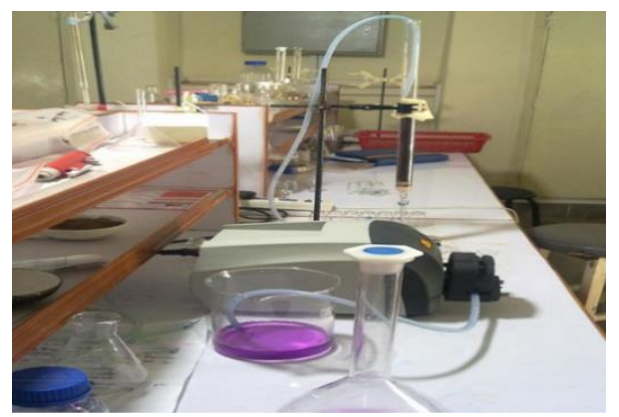

Figure 1. Fixed bedcolumn apparatus.

2.6.2. Column study parameters.

\subsubsection{Effect of Bed Heigh.}

The breakthrough curves are generated for crystal violet adsorption onto camaldulensis biomass at different bed heights $(10-15-20 \mathrm{~cm})$. Breakthrough time determines the process; the larger the breakthrough time, the higher the adsorption capacity of the adsorbent in the column. This is because the dye molecule got more time in contact with the adsorbent [10].

\subsubsection{Effect of solution flow rate.}

In the continuous mode of the experiment, the flow rate is also an important parameter. The effect of flow rate on breakthrough curves was also evaluated using three flow rates (2.5, $\left.5,10 \mathrm{mlmin}^{-1}\right)$, keeping the bed height and initial dye concentration $\left(10 \mathrm{~cm}\right.$ and $\left.25 \mathrm{mgL}^{-1}\right)$ constant [35].

\subsubsection{Effect of initial dye concentration.}

The effect of initial dye concentration was justified by taking different dye concentration of crystal violet dye that ranges from 10 to $75 \mathrm{mgL}^{-1}$ having a constant bed height of $10 \mathrm{~cm}$ and flow rate of $1 \mathrm{mLmin}^{-1}[14]$. 
2.6.6. Effect of $\mathrm{pH}$.

$\mathrm{pH}$ greatly influence the adsorption capacity of the adsorbent. For this purpose, the fixed bed experiments were conducted on wide $\mathrm{pH}$, i.e., 5, 6.5, 9, 11 [15].

\subsection{Justification of Thomas model application.}

\subsubsection{Langmuir isotherm.}

$\mathrm{K}$ ads $=$ Constant rate of adsorption $\left(\mathrm{Lmg}^{-1}\right) \mathrm{In}$ Langmuir isotherm, it is presumed that there will be no interaction between the adsorbed molecules, and the nature of the adsorption will be monolayer. A single-layer of adsorbent molecules saturates the adsorbent surface [25]. The linearized Langmuir isotherm equation is represented as:

$$
\begin{gathered}
K_{a d s} Q_{\text {max }} \mathrm{C}_{\mathrm{e}} \\
\boldsymbol{q}_{c=1+\mathrm{K}_{\text {a d s }} \mathrm{Ce}}
\end{gathered}
$$

where, $\mathrm{C}_{\mathrm{e}}=$ Equilibrium concentration $\left(\mathrm{mgL}^{-1}\right), \mathrm{q}_{\mathrm{e}}=$ Amount of contaminant adsorbed /unit mass of adsorbent $\left(\mathrm{mgg}^{-1}\right), \mathrm{Q}_{\max }=$ Maximum adsorption capacity $\left(\mathrm{mgg}^{-1}\right)$

\subsubsection{Pseudo-second order kinetics model.}

The pseudo-second-order model is based on the assumption that the rate-limiting step may be chemisorption. It involves sharing of electrons between the adsorbent and the adsorbate. Adsorption capacity, the rate constant of pseudo-second-order, and the initial adsorption rate can be directly determined from the equation where other parameters like (temperature, $\mathrm{pH}$, and particle size) are not necessary [30].

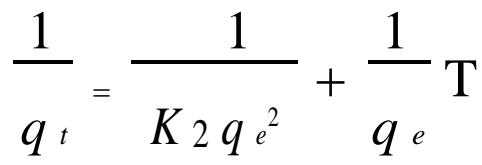

Where, $\mathrm{k}_{2}(\mathrm{~g} / \mathrm{mg} . \mathrm{hr})=$ pseudo 2 nd order rate constant, $\mathrm{q}_{\mathrm{t}}(\mathrm{mg} / \mathrm{g})$ =amount of adsorbate adsorbed at time $\mathrm{t}, \mathrm{qe}(\mathrm{mg} / \mathrm{g})=$ equilibrium adsorption capacity.

\subsubsection{Thomas model.}

Thomas model is mostly used to describe the fixed bed column performance and the prediction of breakthrough curve. Thomas model is associated with the batch experiments as well, as it follows the Langmuir model and pseudo-second-order to verify the assumption that there is no axial dispersion and it obeys pseudo-second-order kinetics. The regression coefficient can be estimated earlier by assuming that its conditions are favorable or unfavorable [29].

The linearized form of the Thomas model can be expressed as follows:

$$
\frac{\ln \left({ }^{C 0}\right)-1=}{C_{f}}=\frac{{ }^{K t h m q 0}-K_{t h} C_{0} t}{Q}
$$

Where, $\mathrm{K}_{\text {th }}(\mathrm{mL} / \mathrm{min} \mathrm{mg})=$ Thomas rate constant, $\mathrm{M}=$ Mass of adsorbent $(\mathrm{g}), \mathrm{C}_{\mathrm{o}}=$ Inlet dye concentration $\left(\mathrm{mgL}^{-1}\right), \mathrm{C}_{\mathrm{f}}=$ Outlet concentration $\left(\mathrm{mgL}^{-1}\right)$ at time $\mathrm{t}, \mathrm{q}_{\mathrm{o}}=$ Adsorption capacity $\left(\mathrm{mgg}^{-1}\right), \mathrm{Q}=$ flow rate in $\mathrm{mL} / \mathrm{min}, \mathrm{t}=$ Total time that represents the flow time. 
The linear plot of $\ln (\mathrm{Co} / \mathrm{Ct}-1)$ vs. time was plotted to obtain the values of kth and qo by using the values of intercept and slope.

\subsubsection{Breakthrough curve.}

The breakthrough curve plots the concentration measured at any point in the column against time t. It also shows the loading behavior of adsorbed dye onto the adsorbent. It is expressed as the ratio of outlet dye concentration to the inlet concentration and plotted against time, i.e., Ct/Co vs. t, whereas the effluent volume can be calculated as [39].

$$
{ }^{V} \text { ef } f=F \cdot t
$$

Whereas, $\mathrm{F}=$ Total Flow $(\mathrm{mL} / \mathrm{min}), \mathrm{T}=$ Total time $(\mathrm{min})$

Breakthrough capacity Q0.5 (at 50\%) expressed in mg of dye adsorbed per gram of bioadsorbent which can be calculated by the following equation

$$
Q_{0.5=} \frac{B . T^{*} \text { flow rate* inlet conc } .}{M}
$$

Whereas, $\mathrm{Q}_{0.5}=$ Breakthrough time at $50 \%$, Flow rate $=\mathrm{mL} / \mathrm{min}$, Inlet concentration $=\left(\mathrm{mgL}^{-}\right.$ $\left.{ }^{1}\right), \mathrm{M}=$ Mass of bioadsorbent $(\mathrm{g})$

\section{Results and Discussion}

\subsection{Isotherm and kinetics models.}

Thomas model applies to the adsorption data if the latter obey the following: (i) the adsorption data should obey Langmuir isotherms; (ii) the adsorption data should also follow the pseudo-second-order kinetics. Different initial dye concentrations (10, 30, 40, $\left.70 \mathrm{mgL}^{-1}\right)$ were simulated in batch experiment [36]. In the present study, data best fit Langmuir's isotherm $\left(\mathrm{R}^{2}\right.$ 0.96) and followed the pseudo-second-order reaction at $30 \mathrm{mgL}^{-1}\left(\mathrm{R}^{2} 0.996\right)$.

\subsection{Column Adsorption for Eucalyptus camaldulensis.}

The adsorption capacity of Eucalyptus camaldulensis biomass was evaluated at different bed heights, flow rate, $\mathrm{pH}$, and initial dye concentrations.

\subsubsection{Effect of Bed Height.}

Glass columns filled with different adsorbent doses occupying variable bed depths were prepared and subjected to flow of $1 \mathrm{mlmin}^{-1}$ containing $20 \mathrm{mgL}^{-1}$ initial dye concentration aqueous solutions with $\mathrm{pH} 6.7$ at room temperature across 10, 15, and $20 \mathrm{~cm}$ bed height. It was observed that mass transfer zone and breakthrough curved was obtained at 600 minutes service time at bed height of $20 \mathrm{~cm}$, which was quite higher compared to bed heights $10 \mathrm{~cm}$ and $15 \mathrm{~cm}$ (Fig 2).

\subsubsection{Effect of flow rate.}

The flow rate of the contaminant in any designed fixed-bed column plays an important role in determining the efficiency of the process. Higher flow rates allow the contaminant to keep in contact with the adsorbent for less time than cases where slower flow rates are applied. To assess the effect of flow rate on the adsorption process, variable flow rates of $1 \mathrm{mlmin}^{-1}, 5$ 
$\mathrm{mlmin}^{-1}$ and $10 \mathrm{mlmin}^{-1}$ aqueous solutions were conducted at column bed depth of $10 \mathrm{~cm}, 20$ $\mathrm{mgL}^{-1}$ initial dye concentration, $\mathrm{pH} 6.57$ at room temperature [24].

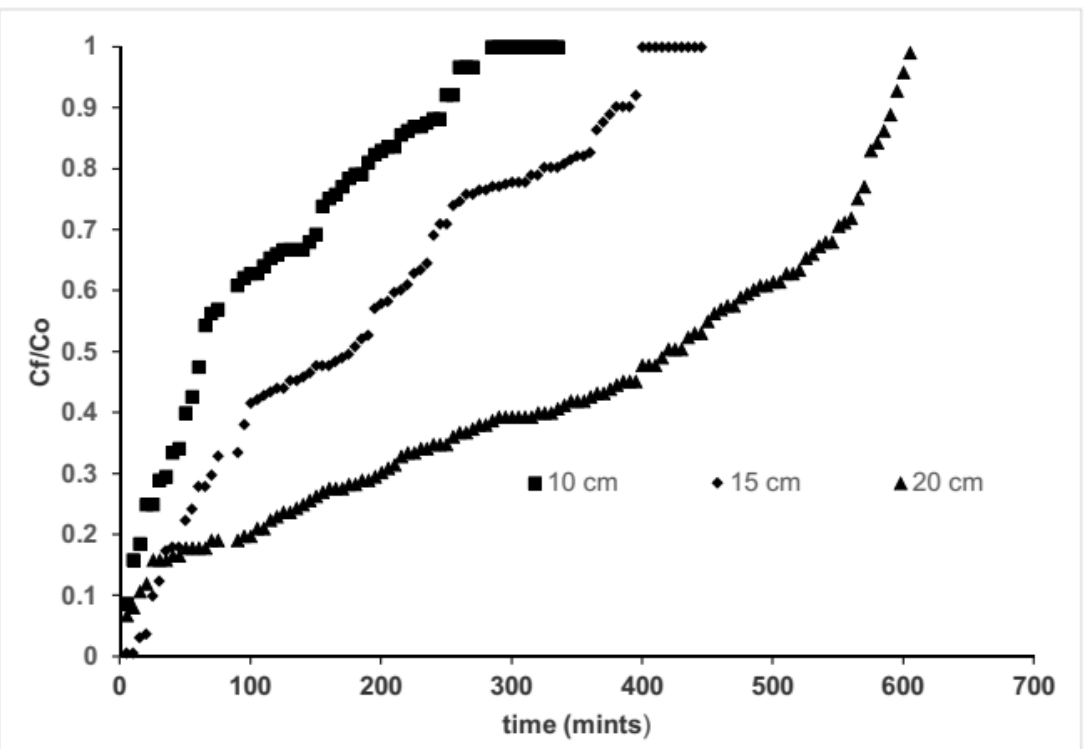

Figure 2. Breakthrough value for Bed Height.

It was observed that column exhaust time reached much earlier at higher flow rates than slower flow rates. Column exhausted at 180 mints contact time at a flow rate of $10 \mathrm{mlmin}^{-1}$ which is much quicker than $1 \mathrm{mlmin}^{-1}$ which exhausted at 300 min contact time (Fig 3).

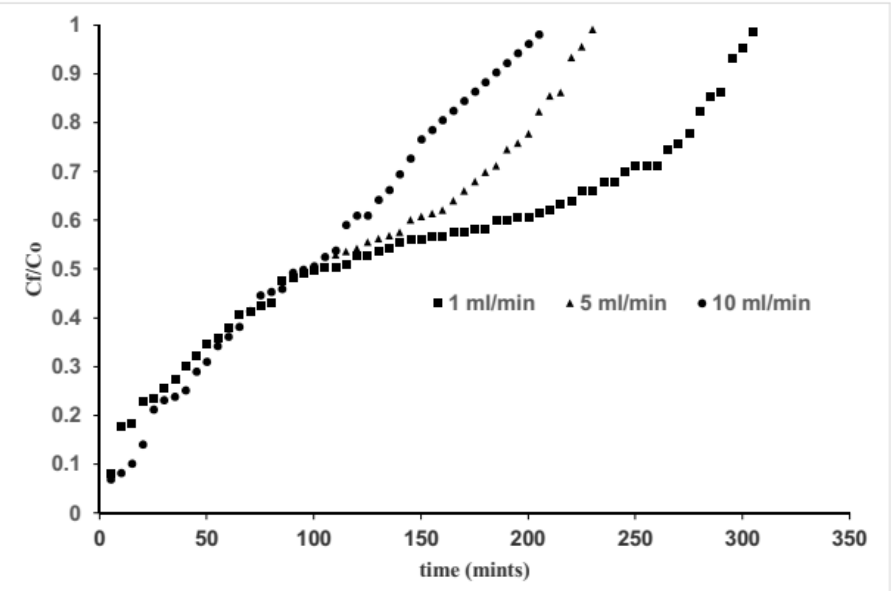

Figure 3. Breakthrough curve for flow rate.

\subsubsection{Effect of $\mathrm{pH}$.}

The $\mathrm{pH}$ of the effluents has a significant role in affecting the rate of contaminant adsorption onto the surface of the adsorbents. Variability of adsorbent surface charges is mainly governed by changes in the $\mathrm{pH}$ of the wastewater. Acidic and basic conditions are equally responsible for affecting the mechanisms responsible for binding contaminants onto the surface of the adsorbent. To assess the effect of effluent $\mathrm{pH}$ on the adsorption process, column experiment was carried out under different initial inlet $\mathrm{pH}$ conditions of $\mathrm{pH} 5,6.5,9$, and 11 at a flow rate of $1 \mathrm{mlmin}^{-1}$ and bed depth of $10 \mathrm{~cm}$. It was noted that maximum adsorption was taking place under acidic conditions [36]. The breakthrough curve was obtained late in the case of pH 5 initial dye concentration compared to other tested effluent $\mathrm{pH}$ values (Fig. 4). 


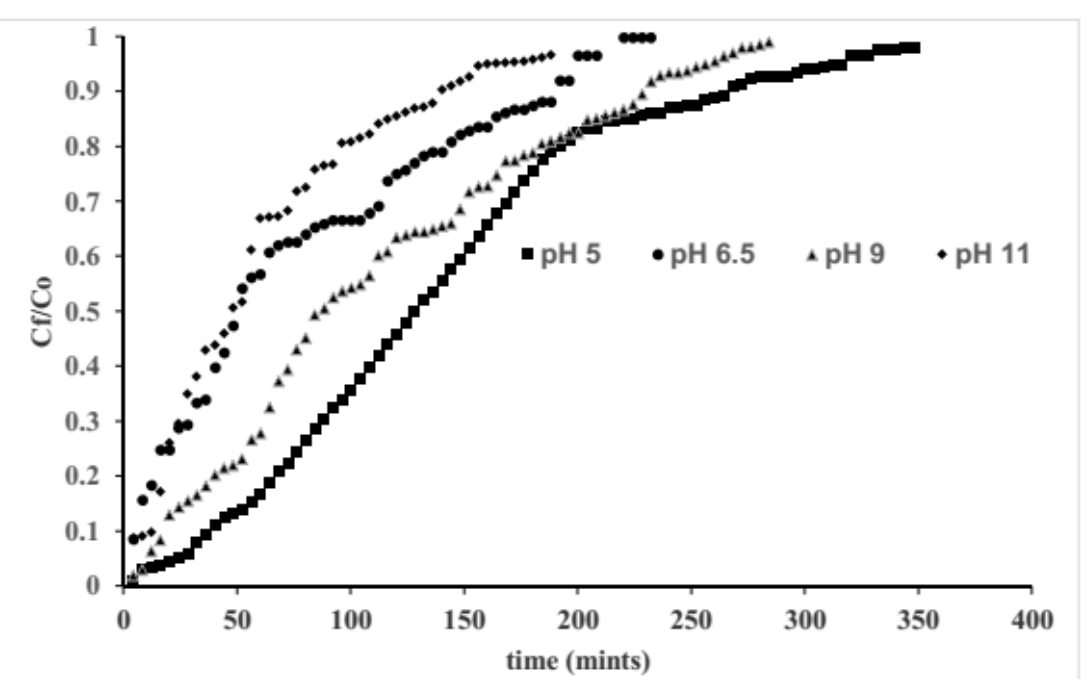

Figure 4. Breakthrough curve for $\mathrm{pH}$.

\subsubsection{Effect of initial dye concentration.}

Initial dye concentration is also an important parameter significantly affecting the adsorption process. Higher initial dye concentrations resulted in earlier breakthrough curves as compared to low initial dye concentration. In the current study, fix bed columns were subjected to three different initial inlet dye concentrations of 20,50 , and $75 \mathrm{mgL}^{-1}$ at a constant bed depth of $10 \mathrm{~cm}$ and $\mathrm{pH} 6.75$ (Fig 5).

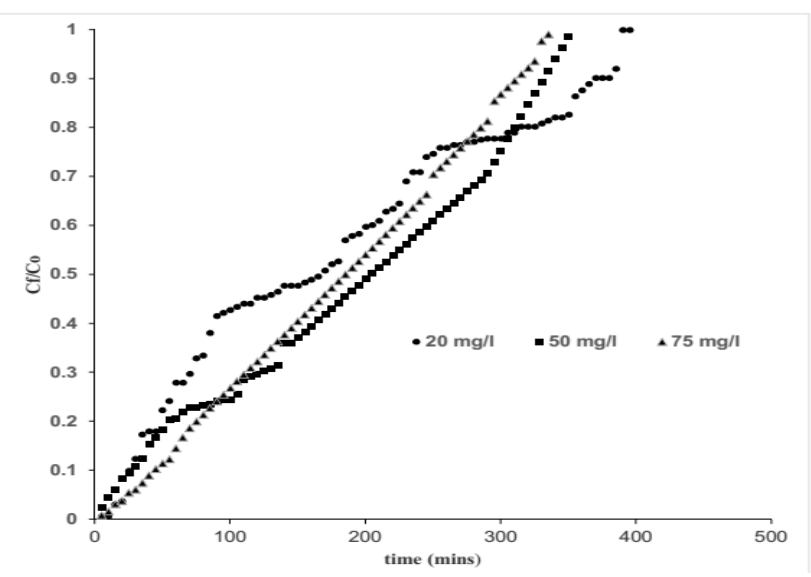

Figure 5. Effect of initial dye concentration on breakthrough curve.

Table 1. Breakthrough values at 50 percent exhaust time.

\begin{tabular}{c|c|c|c|c|c|c} 
& Initial dye & Bed height & flow rate & Vol treated & BT point & Adsorption \\
\hline & mgL $^{-1}$ & $\mathbf{c m}$ & mlmin $^{-1}$ & $\mathbf{V}$ & at 50\% & mgg $^{-1}$ \\
\hline \multirow{3}{*}{ Bed Height } & 20 & 10 & 1 & 1 & 225 & 0.9 \\
\cline { 2 - 7 } & 20 & 15 & 1 & 1 & 300 & 1.2 \\
\cline { 2 - 7 } & 20 & 20 & 1 & 1.5 & 425 & 1.7 \\
\hline \multirow{3}{*}{ Flow Rate } & 20 & 10 & 1 & 1 & 185 & 0.74 \\
\cline { 2 - 7 } & 20 & 10 & 5 & 1 & 105 & 2.1 \\
\cline { 2 - 7 } & 20 & 10 & 10 & 1 & 85 & 3.4 \\
\hline pH 5 & 22 & 10 & 1 & 1 & 190 & 0.76 \\
\hline pH 9 & 22 & 10 & 1 & 1 & 108 & 0.47 \\
\hline pH 11 & 21 & 10 & 1 & 1 & 60 & 0.252 \\
\hline \multirow{3}{*}{ Dye } & 20 & 10 & 1 & 1 & 160 & 0.64 \\
\cline { 2 - 7 } concentration & & & & & & \\
\cline { 2 - 7 } & 75 & 10 & 1 & 1 & 90 & 0.9 \\
\cline { 2 - 7 } & & 10 & 1 & 1 & 105 & 1.575
\end{tabular}




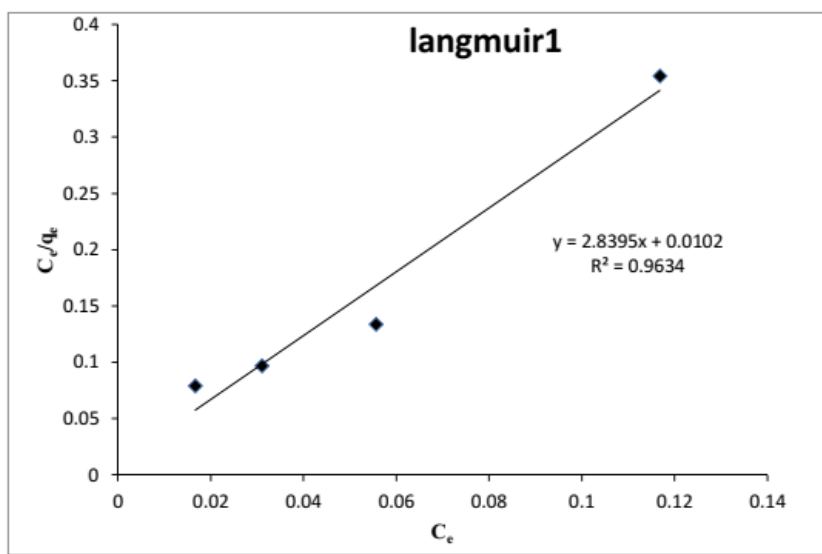

Figure 6. Langmuir isotherm model.

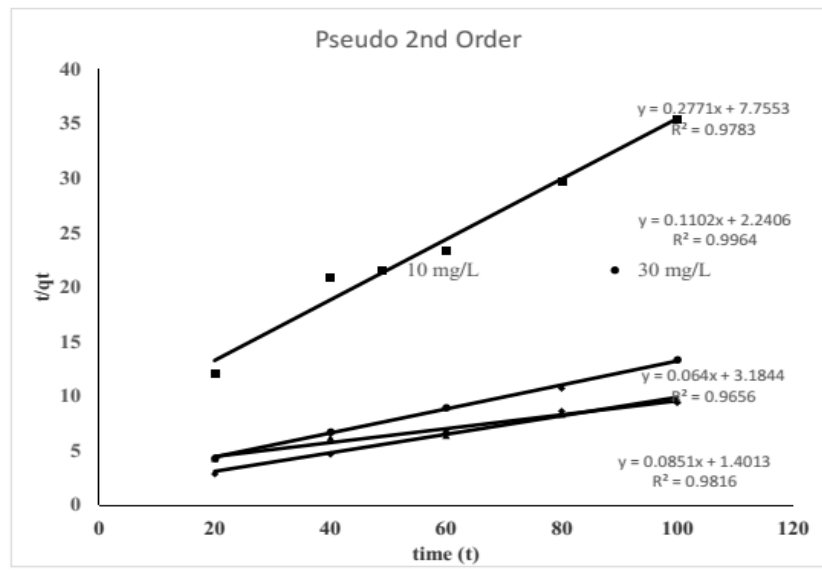

Figure 7. Pseudo -Second Order Reaction Model.

\subsubsection{Justification for Thomas model.}

Thomas model calculates the sorption rate constant and the solid phase concentration of the dye on the adsorbent from the continuous mode study. It estimates the adsorptive capacity of the adsorbent and predicts breakthrough curves, assuming the second-order reversible reaction kinetics and the Langmuir isotherm. Normally process follows the Langmuir, where there is no axial dispersion theoretically. It is suitable to estimate the adsorption process where external and internal diffusion resistances are extremely small. The isotherm follows the Langmuir assumptions $\left(\mathrm{R}^{2} 0.9634\right)$. The results show that data favors pseudo-second-order, which reflects the chemisorption nature [40].

\subsubsection{Thomas model for Bed Height.}

The graph was plotted among the values of natural log (ln) vs. time. The Kth rate constants and qo were obtained from the slope. The regression coefficients support the breakthrough values in the fixed bed column (figure 8). Different bed heights were utilized to study the column behavior, and it was found that all bed heights follow the Thomas model coefficient [41].

\subsubsection{Thomas model for flow rate.}

The values in different flow rates support the Thomas model. The rate constants and adsorption capacity of the bed are given in Table 2. Little fluctuations were observed in the adsorption data that is probably because of the color of the adsorbent. Good regression 
coefficients were obtained at a lower flow rate than those at higher flow rates (figure 9). However, the breakthrough curve confirms the Thomas model and fulfills its assumptions $[42,45]$.

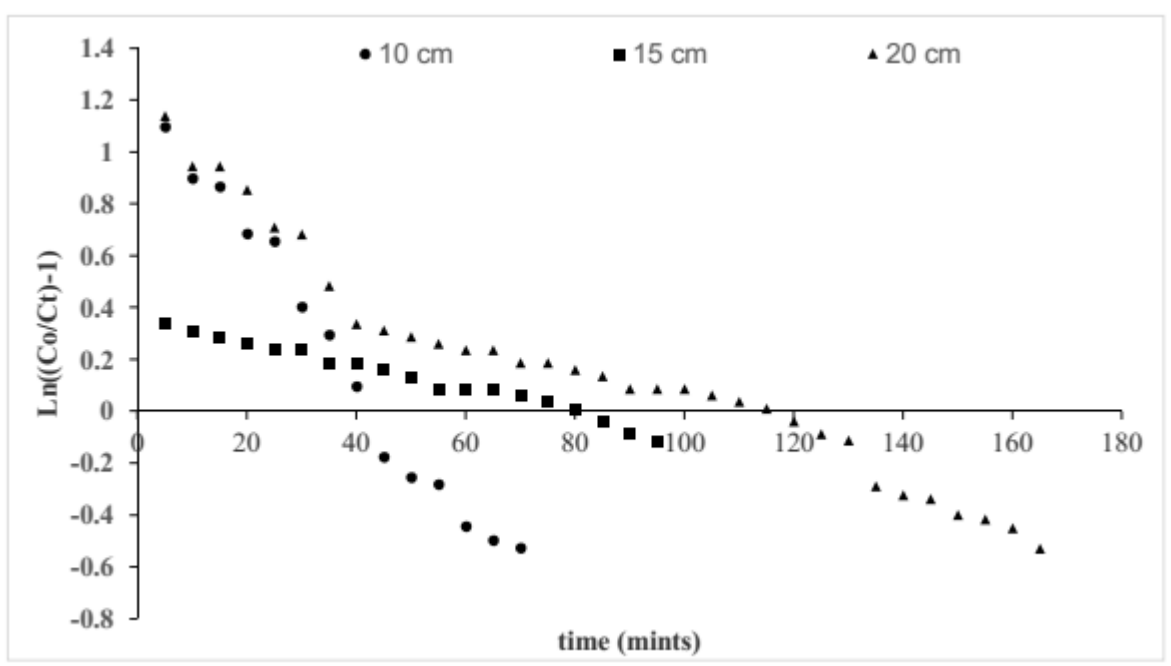

Figure 8. Thomas model for Bed Height.

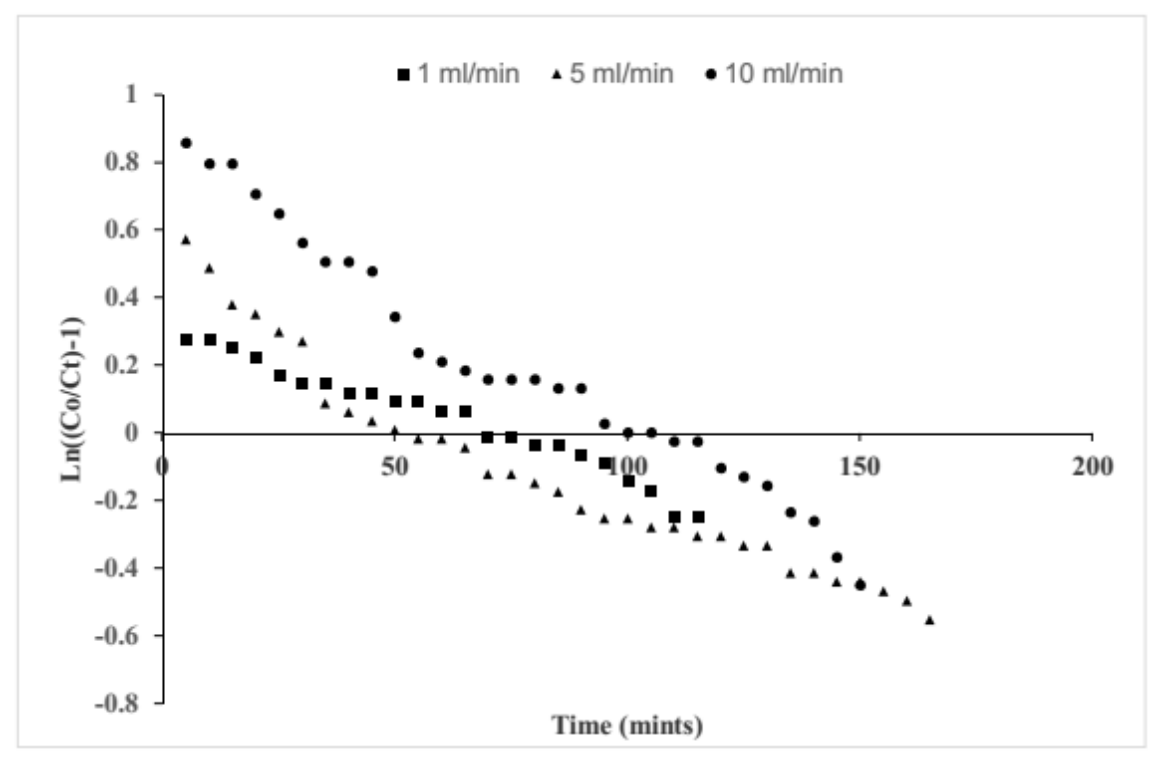

Figure 9. Thomas Model for flow rate.

\subsubsection{Thomas model and initial dye concentration/}

The difference in concentration effect, the rate constants, and behavior of the breakthrough curve were observed (figure 10). The regression value obtained good at a high concentration of $50 \mathrm{mgL}^{-1}$ the data support the Thomas rate constants while the adsorption rates and breakthrough curves also favor the Thomas values. 


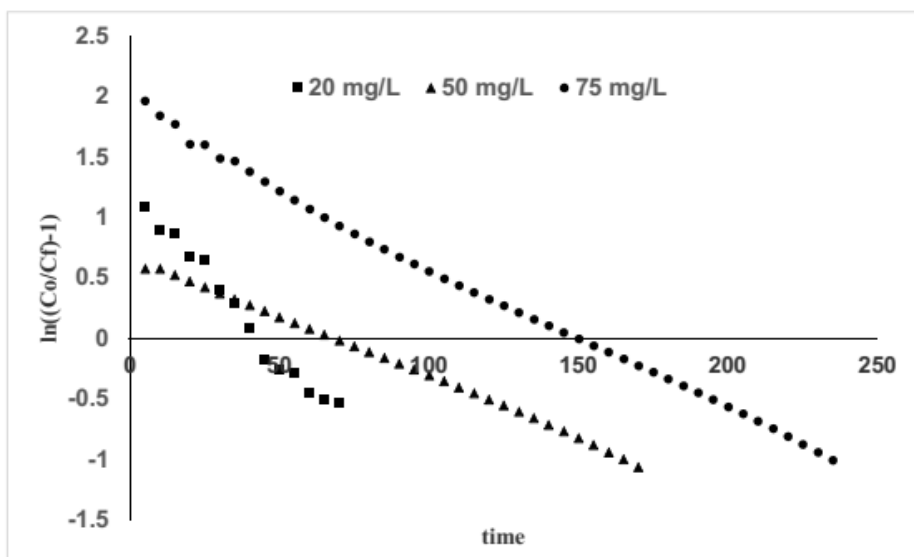

Figure 10. Thomas Model for initial dye concentration.

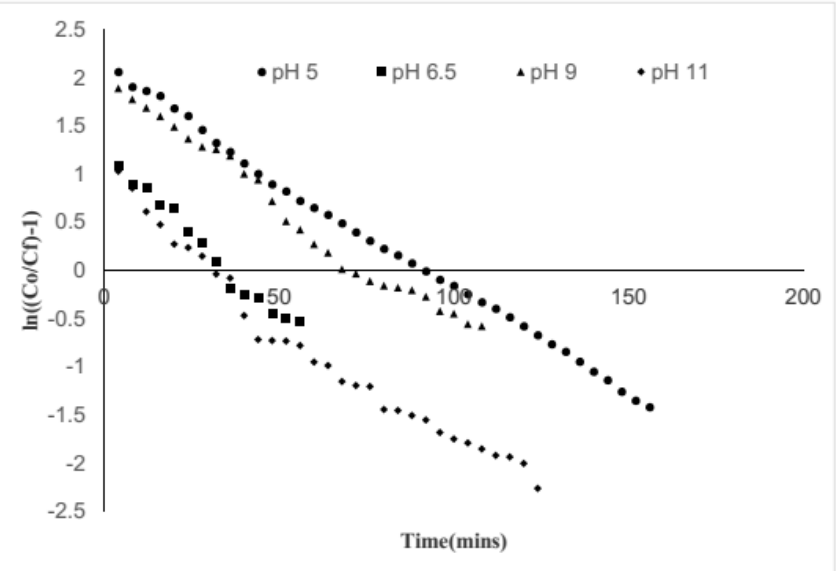

Figure 11. Thomas model for different $\mathrm{pH}$ values.

\subsubsection{Thomas model and $\mathrm{pH}$.}

$\mathrm{pH}$ plays an important role in the column adsorption parameter. The regression values were fit at lower $\mathrm{pH}$, and it supports the breakthrough curve obtained at lower $\mathrm{pH}$ compared to higher ones (figure 11). The kth and qo values were best fitted at acidic $\mathrm{pH}[45,48]$.

Table 2. Calculations of the Thomas Model.

\begin{tabular}{|c|c|c|c|c|c|c|c|}
\hline Parameters & Inlet concentration & Bed height & Flow rate & pH & Kth & Qo & $\mathbf{R}^{2}$ \\
\hline & $\left(\mathrm{mgL}^{-1}\right)$ & $(\mathbf{c m})$ & $\left(\mathrm{mlmin}^{-1}\right)$ & & mLmin $^{-}$ & $\mathrm{Mgg}^{-1}$ & \\
\hline & & & & & $1 \mathrm{mg}^{-1}$ & & \\
\hline \multirow[t]{3}{*}{ Bed Depth } & 20 & 10 & 1 & 6.57 & 1.35 & 0.1804 & 0.9783 \\
\hline & 20 & 15 & 1 & 6.57 & 2.23 & 0.181 & 0.9824 \\
\hline & 20 & 20 & 1 & 6.57 & 3.35 & 0.336 & 0.9663 \\
\hline \multirow[t]{3}{*}{ Flow Rate } & 20 & 10 & 1 & 6.57 & 2.25 & 0.28 & 0.972 \\
\hline & 20 & 10 & 5 & 6.57 & 3 & 0.262 & 0.9348 \\
\hline & 20 & 10 & 10 & 6.57 & 3.5 & 0.3 & 0.9678 \\
\hline \multirow[t]{3}{*}{$\mathrm{pH}$} & 22 & 10 & 1 & 5 & 1.01 & 0.4 & 0.9988 \\
\hline & 22 & 10 & 1 & 9 & 1.15 & 0.34 & 0.9462 \\
\hline & 21 & 10 & 1 & 11 & 1.2 & 0.126 & 0.974 \\
\hline \multirow[t]{3}{*}{ Dye Conc. } & 20 & 10 & 1 & 6.57 & 1.35 & 0.18 & 0.9783 \\
\hline & 50 & 10 & 1 & 6.57 & 2 & 0.67 & 0.9989 \\
\hline & 75 & 10 & 1 & 6.57 & 1.62 & 2.27 & 0.9958 \\
\hline
\end{tabular}




\subsection{Effect of different bed depths on breakthrough curve.}

The effect of bed depth on adsorption of crystal violet dye onto Eucalyptus camaldulensis as an adsorbent was testified by changing the bed depth from $10 \mathrm{~cm}$ to $20 \mathrm{~cm}$ by keeping flow rate $\left(1 \mathrm{mlmin}^{-1}\right)$, initial dye concentration $\left(25 \mathrm{mgL}^{-1}\right)$ constant $[16,20,25]$. The column was packed, having various bed heights of $10 \mathrm{~cm}, 15 \mathrm{~cm}$, and $20 \mathrm{~cm}$ having $5 \mathrm{~g}, 9 \mathrm{~g}$, and $13 \mathrm{~g}$ of mass, respectively. The breakthrough curve was obtained by plotting $\mathrm{Cf} / \mathrm{Co}$ against time. It can be presumed that the breakthrough curve was obtained later and increased the effluent volume and exhaustion time by increasing the bed height. With increasing bed depth, the volume of treated effluents increases due to more available binding sites [29,32]. The increase in the adsorbent bed leads to more adsorption of the adsorbate as more availability of surface area. By decreasing the bed depth, the diffusion process also decreases in MTZ, reducing the diffusion of dye ions. With less availability of the adsorbent, the ions of dyes got minimum chances to be in contact with the adsorbent results in low adsorption $[27,38]$.

\subsection{Effect of flow rate on breakthrough curve.}

The effect of flow rate on the adsorption of crystal violet Eucalyptus camaldulensis biomass was explored by changing the flow rate (1-5-10 $\left.\mathrm{mlmin}^{-1}\right)$ while keeping bed depth as $10 \mathrm{~cm}$ and inlet dye concentration of $20 \mathrm{mgL}^{-1}$ constant across fix bed column. It was recorded that at a higher flow rate, the breakthrough was obtained earlier and led to the saturation point in advance $[39,40]$. But when the flow rate was reduced, the breakthrough time and saturation time appeared later. At a lower flow rate, the dye molecules get more time to be in contact with the adsorbent and hence lead to higher adsorption; thus, column exhausts consume more time compared to the former case. The changes in the breakthrough curves and slopes can be determined by the factor MTZ. The adsorption capacity is minor at lower contact time due to the high flow rate [38]. The diffusion rate is slower, and the dye molecule left the column earlier, previous to the establishment of equilibrium time; this result is verified from the other available literature.

\subsection{Effect of initial dye concentration.}

The execution of the inlet crystal violet dye concentration from $10-75 \mathrm{mgL}^{-1}$ was carried out under the same constant experimental conditions like bed height, $\mathrm{pH}$, flow rate, and temperature. As far as concentration was increasing, the breakthrough curve slightly decreased [25]. At lower concentrations, the breakthrough curve appears late due to the low diffusion of dye ions. Our adsorbent was found not effective at very low and diluted dye contaminant concentrations. The column was exhausted in no time recorded as 50 minutes. However, the breakthrough curve was attained faster by increasing the initial dye concentration. The breakthrough curve was attained later at lower dye concentration due to the slower transport of dye ions and decreased mass transfer coefficient. Different literature shows similar results regarding adsorption behavior in a column. The highest adsorption capacity obtained was (1.575 mgg ${ }^{-1}$ ) using $75 \mathrm{mgL}^{-1}$ concentration at bed height of $10 \mathrm{~cm}$ with the flow rate of 1 $\operatorname{mlmin}^{-1}[29]$. The adsorption capacities obtained are listed in Table 1. 


\subsection{Effect of $\mathrm{pH}$.}

The most important parameter that influences the adsorption capacity of any adsorbent is $\mathrm{pH}$. The initial $\mathrm{pH}$ of the bio-adsorption medium is affiliated to the sorption tool onto the adsorbent surface from water and sends back the nature of the physiochemical communication of the species in the solution and the available adsorption sites of the adsorbent being used [39]. The consequences of $\mathrm{pH}$ onto the breakthrough curve and time were noticed at various $\mathrm{pH}$ levels ranging from $\mathrm{pH} 5$ to 11 by keeping other experimental conditions constant. Values on adsorption of crystal violet dye onto the Eucalyptus camaldulensis by using a plot of linearized concentration $(\mathrm{Ct} / \mathrm{Co})$ versus time $(\mathrm{t})$. As $\mathrm{pH}$ started to fall from the basic conditions, i.e., $\mathrm{pH}$ 11, the breakthrough curve was attained with less adsorption capacity, and values of $\mathrm{Ct} / \mathrm{Co}$ reached 0.99 in a short time. As the $\mathrm{pH}$ of the aqueous dye solution was lowered to acidic conditions at $\mathrm{pH} .5$, the breakthrough curve time increased and showed more adsorption of the dye; the efficiency of the adsorbent was high under acidic $\mathrm{pH}$ conditions of the aqueous dye solution [41] the results show that by decreasing the $\mathrm{pH}$. The adsorption capacity increases, so it can be assumed that removing crystal violet dye from the aqueous solution at lower $\mathrm{pH}$ was more efficient.

\subsection{Application of Thomas model on Bed Height breakthrough curves.}

The column data were fitted well with the Thomas model to determine the Thomas rate constant (kth), maximum solid-phase concentration (qe), and regression coefficient $\left(\mathrm{R}^{2}\right)$. The $\mathrm{R}^{2}$ wasin the range of (0.993-0.997), which indicates that the correlation of $\mathrm{Ct} / \mathrm{Co}$ and $\mathrm{t}$ according to Thomas equation is significant $[42,44]$. The results indicate that there is no significant change in the values of qo, but kth values differ concerning bed height. At a higher Kth value, the adsorption capacity was low and vice versa (Table 1). However, moderate adsorption was noticed at $20 \mathrm{~cm}$ of bed height. Because the adsorbent is first pre-washed with deionized water, and later on, the adsorbate was passed through, reflecting little fluctuations in the values of qo. However, regression values favored the application of the Thomas model.

\subsection{Application of Thomas model on flow rate breakthrough curves.}

The adsorption capacity was low at a higher value of Kth. At a higher flow rate, the adsorption capacity was low and, resultantly, the higher Kth value. Similarly, at a lower flow rate, the adsorption capacity was found comparatively high and lower Kth. It is because of the driving force of the concentration difference between the dye on the adsorbent and in the aqueous solution (Thomas 1944). The regression values for different flow rates follow the Thomas model.

\subsection{Application of Thomas model on the initial dye concentration breakthrough curves.}

The coefficient of determination $\left(\mathrm{R}^{2}\right)$ for initial dye concentration indicated that at a higher initial dye concentration, the adsorption capacity was higher with a lower kth value. Similarly, the adsorption capacity was observed high at lower initial dye concentration, but Kth values were also observed high. However, overall performance is affected by the adsorbent color that needs to be removed completely for obtaining high adsorption capacity [25]. The regression values of different initial dye concentrations follow the Thomas model (Table 2). 


\subsection{Impact of pH on breakthrough curves and Thomas model application.}

The role of $\mathrm{pH}$ plays a very important in the adsorption phenomenon. Breakthrough curves data follow the Thomas model and its assumptions. At lower $\mathrm{pH}$, the adsorption capacity was observed high compared to the other $\mathrm{pH}$ values, whereas Kth was lower. Similarly, at a high $\mathrm{pH}$ value, the Kth and the adsorption capacity have been observed low [30]. The adsorption capacity was also high at $\mathrm{pH} 9$ as compared to $\mathrm{pH} 11$. A lower Kth value resulted from a high adsorption value compared to $\mathrm{pH} 11$, which reflected a high kth value and lower sorption capacity (Table 2). Overall, when $\mathrm{pH}$ moved towards acidic, the sorption capacity increased, and breakthrough time appeared later than basic $\mathrm{pH}$.

\section{Conclusions}

Dyes are the primary pollutant and have a negative impact on human and aquatic life. Many treatments were introduced to treat textile wastewater, but they were restricted due to high operational costs. Adsorption is one of the most favorable upcoming methods of wastewater treatment. Surplus biomasses that are abundant can be explored as operative bioadsorbent. The breakthrough time and mass transfer zone phenomenon were observed at different bed heights, flow rates, initial dye concentrations, and $\mathrm{pH}$. It was noticed that breakthrough time was increased up to $600 \mathrm{~min}$ at $20 \mathrm{~cm}$. The result reveals that the exhaust time will be higher at high bed heights and vice versa. Similarly, at lower flow rates and lower initial dye concentrations, the exhaust time gets long and vice versa. The significant results were obtained at lower $\mathrm{pH} 5$. The breakthrough curve and acceptable adsorption capacity were noticed at acidic $\mathrm{pH}$. The acidic $\mathrm{pH}$ was suitable for the adsorption of different dye concentration solutions. The adsorption capacity was significantly high, and mass transfer and breakthrough curves later favored the Thomas model. The column exhaust time ranged from 390 to $600 \mathrm{~min}$. The dye removal and exhaust time increased with increased bed height. The high initial dye concentration and high flow rate caused exhaustion in a shorter time because it fasters the mass transfer zone. Thomas's model fits well with the column adsorption data. However, the overall adsorption capacity was found to be less during experimentation. The color compounds resist the adsorption, and this phenomenon is reduced by adjusting $\mathrm{pH}$ at an acidic medium. The R2 values range from (0.93-0.997), and the breakthrough values obtained from the data favor the Thomas model. It is concluded that Eucalyptus camaldulensis, which is abundant biomass in northern areas and Punjab province, can be applied in textile wastewater treatment operations.

\section{Funding}

This research received no external funding.

\section{Acknowledgments}

This research has no acknowledgment.

\section{Conflicts of Interest}

The authors declare no conflict of interest. 


\section{References}

1. Zheng, S.-A.; Zheng, X.; Chen, C. Leaching Behavior of Heavy Metals and Transformation of Their Speciation in Polluted Soil Receiving Simulated Acid Rain. Plos One 2012, 7, 4966049664,https://doi.org/10.1371/journal.pone.0049664.

2. Zhang, J.-E.; Ouyang, Y.; Ling, D.-J. Impacts of simulated acid rain on cation leaching from the Latosol in south China. Chemosphere 2007, 67, 2131-2137, https://doi.org/10.1016/j.chemosphere.2006.12.095.

3. Cullis, C.F.; Hirschler, M.M. Atmospheric sulphur: Natural and man-made sources. Atmospheric Environment (1967) 1980, 14, 1263-1278, https://doi.org/10.1016/0004-6981(80)90228-0.

4. Liu, K.-H.; Fang, Y.-T.; Yu, F.-M.; Liu, Q.; Li, F.-R.; Peng, S.-L. Soil Acidification in Response to Acid Deposition in Three Subtropical Forests of Subtropical China. Pedosphere 2010, 20, 399-408, https://doi.org/10.1016/S1002-0160(10)60029-X.

5. Lal, N. The effects of simulated acid rain of different pH-levels on biomass and leaf area in Sunflower (Helianthus annuus). Current Botany 2013, 3, 45-50.

6. Evans, L.S.; Lewin, K.F.; Conway, C.A.; Patti, M.J. Seed Yields (Quantity And Quality) Of Field-Grown Soybeans Exposed To Simulated Acidic Rain. New Phytologist 1981, 89, 459-470, https://doi.org/10.1111/j.1469-8137.1981.tb02327.x.

7. Evans, L.S.; Lewin, K.F. Growth, development and yield responses of pinto beans and soybeans to hydrogen ion concentrations of simulated acidic rain. Environmental and Experimental Botany 1981, 21, 103-113, https://doi.org/10.1016/0098-8472(81)90015-0.

8. Ling, D.-J.; Huang, Q.-C.; Ouyang, Y. Impacts of simulated acid rain on soil enzyme activities in a latosol. $\begin{array}{llllll}\text { Ecotoxicology and } & \text { Environmental }\end{array}$ https://doi.org/10.1016/j.ecoenv.2010.07.024.

9. Li, Y.; Wang, Y.; Wang, Y.; Wang, B. Effects of simulated acid rain on soil respiration and its component in a mixed coniferous-broadleaved forest of the three gorges reservoir area in Southwest China. Forest Ecosystems 2019, 6, 1464-1480, https://doi.org/10.1186/s40663-019-0192-0.

10. Nelson, D.W.; Sommers, L.E. Total carbon, organic carbon and organic matter. In:Methods of Soil Analysis. Part 2. Chemical and Microbiological Properties. Page, A.L.; Miller, R.H.; Keeney, D.R. (Eds.), ASA, SSSA, Madison, WI, USA1982; 539-580.

11. Gee, G.W.; Bauder, J.W. Particle-size analysis. In: Method of Soil Analysis, Part 1.Klute, A. (ed), Agronomy series No. 9. American Societyof Agronomy and Soil Science Society of America Inc. Publ., Madison, W.I. USA, 1986;pp. 383-441.

12. Barančíková, G.; Madaras, M.; Rybár, O. Crop contamination by selected trace elements. Journal of Soils and Sediments2004, 4, 37-42,https://doi.org/10.1007/bf02990827.

13. Narwal, R.P.; Singh, B.R. Effect of Organic Materials on Partitioning, Extractability and Plant Uptake of Metals in an Alum Shale Soil. Water, Air, and Soil Pollution 1998, 103, 405421,https://doi.org/10.1023/A:1004912724284.

14. McBride, M.B.; MartÍnez, C.E. Copper Phytotoxicity in a Contaminated Soil: Remediation Tests with Adsorptive Materials. Environmental Science \& Technology 2000, 34, 43864391,https://doi.org/10.1021/es0009931.

15. Cao, X.; Wahbi, A.; Ma, L.; Li, B.; Yang, Y. Immobilization of $\mathrm{Zn}, \mathrm{Cu}$, and $\mathrm{Pb}$ in contaminated soils using phosphate rock and phosphoric acid. Journal of Hazardous Materials 2009, 164, 555-564, https://doi.org/10.1016/j.jhazmat.2008.08.034.

16. Ure, A.M.; Quevauviller, P.; Muntau, H.; Griepink, B. Speciation of Heavy Metals in Soils and Sediments. An Account of the Improvement and Harmonization of Extraction Techniques Undertaken Under the Auspices of the BCR of the Commission of the European Communities. International Journal of Environmental Analytical Chemistry 1993, 51, 135-151,https://doi.org/10.1080/03067319308027619.

17. Bond-Lamberty, B.; Bailey, V.L.; Chen, M.; Gough, C.M.; Vargas, R. Globally rising soil heterotrophic respiration over recent decades. Nature 2018, 560, 80-83, https://doi.org/10.1038/s41586-018-0358-X.

18. Chen, S.; Zhang, X.; Liu, Y.; Hu, Z.; Shen, X.; Ren, J. Simulated acid rain changed the proportion of heterotrophic respiration in soil respiration in a subtropical secondary forest. Applied Soil Ecology 2015, 86, 148-157,https://doi.org/10.1016/j.apsoil.2014.10.013.

19 Delgado-Baquerizo, M.; Oliverio, A.M.; Brewer, T.E.; Benavent-González, A.; Eldridge, D.J.; Bardgett, R.D.; Maestre, F.T.; Singh, B.K.; Fierer, N. A global atlas of the dominant bacteria found in soil. Science (New York, N.Y.) 2018, 359, 320-325. https://doi.org/10.1126/science.aap9516.

20 Guo, J.; Yang, Z.; Lin, C.; Liu, X.; Chen, G.; Yang, Y. Conversion of a natural evergreen broadleaved forest into coniferous plantations in a subtropical area: effects on composition of soil microbial communities and soil respiration. Biology and Fertility of Soils 2016, 52, 799-809, https://doi.org/10.1007/s00374-016-1120$\mathrm{x}$.

21 Iqbal, J.; Hu, R.; Feng, M.; Lin, S.; Malghani, S.; Ali, I.M. Microbial biomass, and dissolved organic carbon and nitrogen strongly affect soil respiration in different land uses: A case study at Three Gorges Reservoir Area, South China. Agriculture, Ecosystems \& Environment 2010, 137, 294-307, https://doi.org/10.1016/j.agee.2010.02.015. 
22 Jalali, M.;Naderi, E. The impact of acid rain on phosphorus leaching from a sandy loam calcareous soil of western Iran. Environmental Earth Sciences2012, 66, 311-317,https://doi.org/10.1007/s12665-011-1240-4.

23 Jian, J.; Steele, M.K.; Day, S.D.; Thomas, R.Q.; Hodges, S.C. Measurement strategies to account for soil respiration temporal heterogeneity across diverse regions. Soil Biology and Biochemistry2018, 125, 167177,https://doi.org/10.1016/j.soilbio.2018.07.003

24 Liang, G.; Hui, D.; Wu, X.; Wu, J.; Liu, J.; Zhou, G.; Zhang, D. Effects of simulated acid rain on soil respiration and its components in a subtropical mixed conifer and broadleaf forest in southern China. Environmental Science: Processes \& Impacts2016, 18, 246-255, https://doi.org/10.1039/C5EM00434A

25 Meyer, N.; Welp, G.; Amelung, W. Effect of sieving and sample storage on soil respiration and its temperature sensitivity (Q10) in mineral soils from Germany. Biology and Fertility of Soils2019, 55, 825832, https://doi.org/10.1007/s00374-019-01374-7.

26 Xian, X. Effect of chemical forms of cadmium, zinc, and lead in polluted soils on their uptake by cabbage plants. Plant and soil1989, 113, 257-264, https://doi.org/10.1007/BF02280189.

27 Rauta, C.; Lacatusu, R.; Cârstea, S. Heavy metal pollution of soils in Romania. Analele Institutului de Cercetari pentru Pedologie si Agrochimie-1993 (Romania)1996, 52, 237-245

28 Ma,L.Q.;Rao,G.N.Chemicalfractionationofcadmium,copper,nickel,andzincincontaminatedsoils.JournalofEn vironmentalQuality1997,26,259-264, https://doi.org/10.2134/jeq1997.00472425002600010036x.

29 Boon, D.Y.; Soltanpour, P.N. Lead, Cadmium, and Zinc Contamination of Aspen Garden Soils and Vegetation. Journal of Environmental Quality 1992, 21, 82-86, https://doi.org/10.2134/jeq1992.00472425002100010012x.

30 Levy, D.B.; Barbarick, K.A.; Siemer, E.G.; Sommers, L.E. Distribution and Partitioning of Trace Metals in Contaminated Soils near Leadville, Colorado. Journal of Environmental Quality 1992, 21, 185-195, https://doi.org/10.2134/jeq1992.00472425002100020006x.

31 Friesen, C.; Herr, I.; Krammer, P.H.; Debatin, K.-M. Involvement of the CD95 (APO-1/Fas) receptor/ligand system in drug-induced apoptosis in leukemia cells. Nature Medicine 1996, 2, 574-577, https://doi.org/10.1038/nm0596-574.

32 Jung, M.C.; Thornton, I. Environmental contamination and seasonal variation of metals in soils, plants and waters in the paddy fields around a PbZn mine in Korea. Science of The Total Environment 1997, 198, 105121,https://doi.org/10.1016/S0048-9697(97)05434-X.

33 Narwal, R.P.; Singh, B.R. Effect of Organic Materials on Partitioning, Extractability and Plant Uptake of Metals in an Alum Shale Soil. Water, Air, and Soil Pollution 1998, 103, 405-421, https://doi.org/10.1023/A:1004912724284.

34 Mimura,A.M.S.;Vieira,T.D.A.;Martelli,P.B.;Gorgulho,H.D.F.UtilizationofricehusktoremoveCu2+,Al3+,Ni 2+andZn2+fromwastewater.QuímicaNova2010,33,1279-1284, $\quad$ http://dx.doi.org/10.1590/S010040422010000600012.

35 Montanher, S.F.; Oliveira, E.A.; Rollemberg, M.C. Removal of metal ions from aqueous solutions by sorption onto rice bran. Journal of Hazardous Materials 2005, 117, 207-211, https://doi.org/10.1016/j.jhazmat.2004.09.015.

36 Farooq, U.; Khan, M.A.; Athar, M.; Kozinski, J.A. Effect of modification of environmentally friendly biosorbent wheat (Triticum aestivum) on the biosorptive removal of cadmium(II) ions from aqueous solution. Chemical Engineering Journal 2011, 171, 400-410,https://doi.org/10.1016/j.cej.2011.03.094.

37 Witek-Krowiak, A.; Szafran, R.G.; Modelski, S. Biosorption of heavy metals from aqueous solutions onto peanut shell as a low-cost biosorbent. Desalination 2011, 265, 126-134, https://doi.org/10.1016/j.desal.2010.07.042.

38 Satti,Z.;Akhtar,M.;Mazhar,N.;Khan,S.U.;Ahmed,N.;Yasir,Q.M.;Ahmad,W.Adsorptionofcadmiumfromaque oussolutionontountreatedgypsumrockmaterial:Equilibriumandkinetics.BiointerfaceResearchinAppliedChem istry20201 1,10755-10764, https://doi.org/10.33263/BRIAC113.1075510764.

39 Santos, V.C.G.D.; Tarley, C.R.T.; Caetano, J.; Dragunski, D.C. Assessment of chemically modified sugarcane bagasse for lead adsorption from aqueous medium. Water Science and Technology 2010, 62, 457465, https://doi.org/10.2166/wst.2010.291.

40 Azouaou, N.; Sadaoui, Z.; Djaafri, A.; Mokaddem, H. Adsorption of cadmium from aqueous solution onto untreated coffee grounds: Equilibrium, kinetics and thermodynamics. Journal of Hazardous Materials 2010, 184, 126-134, https://doi.org/10.1016/j.jhazmat.2010.08.014.

41 Sun, S.; Yu, Q.; Li, M.; Zhao, H.; Wu, C. Preparation of coffee-shell activated carbon and its application for water vapor adsorption. Renewable Energy 2019, 142, 11-19, https://doi.org/10.1016/j.renene.2019.04.097.

42 Satti,Z.;Akhtar,M.;Mazhar,N.;Khan,S.U.;Naveed,M.;Yasir,Q.M.;Irshad,M.ChangesinSelectedElementsofSo ilsUnderSimulatedAcidRainConditions.BiointerfaceResearchinAppliedChemistry2020,11,1173711746,https://doi.org/10.33263/BRIAC114.1173711746.

43 Mazlan, M.A.F.; Uemura, Y.; Yusup, S.; Elhassan, F.; Uddin, A.; Hiwada, A.; Demiya, M. Activated Carbon from Rubber Wood Sawdust by Carbon Dioxide Activation. Procedia Engineering2016, 148, 530537,https://doi.org/10.1016/j.proeng.2016.06.549. 
44 Wang, J.Y.; Wang, R.Z.; Wang, L.W. Water vapor sorption performance of ACF-CaCl2 and silica gel-CaCl2 composite adsorbents. Applied Thermal Engineering 2016, 100, 893901,https://doi.org/10.1016/j.applthermaleng.2016.02.100.

45 Uzun, B.B.; Yaman, E. Pyrolysis kinetics of walnut shell and waste polyolefins using thermogravimetric analysis. Journal of the Energy Institute 2017, 90, 825-837,https://doi.org/10.1016/j.joei.2016.09.001.

46 Badgley, B.D.; Steele, M.K.; Cappellin, C.; Burger, J.; Jian, J.; Neher, T.P.; Orentas, M.; Wagner, R. Fecal indicator dynamics at the watershed scale: Variable relationships with land use, season, and water chemistry. Science of The Total Environment 2019, 697, https://doi.org/10.1016/j.scitotenv.2019.134113.

47 Gao, X.; Wu, L.; Li, Z.; Xu, Q.; Tian, W.; Wang, R. Preparation and characterization of high surface area activated carbon from pine wood sawdust by fast activation with H3PO4 in a spouted bed. Journal of Material Cycles and Waste Management 2018, 20, 925-936,https://doi.org/10.1007/s10163-017-0653-x.

48 Shahkarami, S.; Azargohar, R.; Dalai, A.K.; Soltan, J. Breakthrough CO2 adsorption in bio-based activated carbons. Journal of Environmental Sciences 2015, 34, 68-76, https://doi.org/10.1016/j.jes.2015.03.008.

49 Sultan, M.; El-Sharkawy, I.I.; Miyazaki, T.; Saha, B.B.; Koyama, S. An overview of solid desiccant dehumidification and air conditioning systems. Renewable and Sustainable Energy Reviews 2015, 46, 16-29, https://doi.org/10.1016/j.rser.2015.02.038. 